\title{
“ADMINISTRAÇÃO DE CATEQUESE E CIVILIZAÇÃO DOS ÍNDIOS” NA PROVÍNCIA DA BAHIA (1836-1887): ENTRE CIVILIZAÇÃO E QUESTÃO DE TERRA
}

\author{
Edilmar Cardoso Ribeiro ${ }^{1}$ \\ Recebido em: 10/02/2021 \\ Aprovado em: 29/03/2021
}

\begin{abstract}
Resumo: Na perspectiva da inserção do indígena na sociedade, este artigo examina a administração de catequese e civilização dos índios na província da Bahia (1836-1887), a partir das orientações e aplicação do Decreto provincial n ${ }^{\circ} 32$, de 1836 e do Decreto imperial $n^{\circ} 426$, de 1845. Por meio de uma abordagem histórico-descritiva, baseada principalmente em fontes primárias - documentos manuscritos (ofícios, relatórios, correspondências) encontrados no Arquivo Público do Estado da Bahia (APEB) e documentos editados (leis e relatórios) - assim como em uma seleta bibliografia, busca-se colocar em confronto e diálogo principalmente a documentação de arquivo dos diversos autores envolvidos direto ou indiretamente no processo de catequese e civilização dos índios. Evidenciou-se os seguintes resultados: o Regulamento de 1836 teve pouca aplicabilidade, pois não deu orientações eficazes e contou com agentes para a catequese que eram insuficientes; o Regulamento de "catequese e civilização dos índios" de 1845 teve aplicação parcial por falta de recursos econômicos, por ser boa parte de suas orientações anacrônicas em relação à realidade dos antigos aldeamentos e das vilas dos índios e por descréditos das autoridades públicas para com este ramo do serviço público; o Regulamento de 1845 não impulsionou a fundação de novos aldeamentos e a nomeação dos diretores para os antigos aldeamentos agravou ainda mais os conflitos em torno da posse da terra e colaborou no processo de usurpação das terras dos índios.
\end{abstract}

Palavras-chave: Catequese e Civilização. Aldeamentos. Resistência indígenas. Terra indígena. Bahia.

\section{“ADMINISTRACIÓN DE CATEQUESIS Y CIVILIZACIÓN DE LOS INDIOS” EN LA PROVINCIA DE BAHIA (1836-1887): ENTRE CIVILIZACIÓN Y CUESTIÓN DE LA TIERRA}

Resumen: En la perspectiva de la inserción de los indígenas en la sociedad, este artículo examina la administración de catequesis y civilización de los indios en la provincia de Bahía (1836-1887), con base en los lineamientos y aplicación del Decreto Provincial n 32 de 1836 y del Decreto Imperial $\mathrm{n}^{\circ} 426$ de 1845 . Mediante un enfoque histórico-descriptivo, basado principalmente en fuentes primarias - documentos manuscritos (cartas, informes, correspondencias) encontrados en el Archivo Público del Estado de Bahía (APEB) y documentos editados (leyes e informes) - así como en una selecta bibliografía, se buscó poner en confronto y dialogo principalmente la documentación de archivo de los diversos autores

\footnotetext{
${ }^{1}$ Doutor em História da Igreja pela Pontifícia Universidade Gregoriana (PUG). Professor Assistente na Pontificia Universidad Católica de Chile. E-mail: edilmar.cardoso@uc.cl. ORCID: https://orcid.org/0000-0002-7622-8891.
} 
involucrados directo o indirectamente en el proceso de catequesis y civilización de los indios. Los resultados logrados son: el Reglamento de 1836 tuvo poca aplicabilidad, ya que no daba pautas efectivas y no contaba con suficientes agentes para la catequesis; el Reglamento de la catequesis y civilización de los indios de 1845 tuvo aplicación parcial por falta de recursos económicos, por ser buena parte de sus orientaciones anacrónicas en relación a la realidad de los antiguos asentamientos y pueblos de indios y por la incredulidad de las autoridades públicas hacia esta rama del servicio público; el Reglamento de 1845 no fomentó la fundación de nuevos asentamientos y el nombramiento de directores para los antiguos asentamientos agravó aún más los conflictos sobre la tenencia de la tierra y contribuyó al proceso de usurpación de las tierras de los indígenas.

Palabras claves: Catequesis y Civilización. Pueblos de indios. Resistencia indígena. Tierra indígena. Bahía.

\section{"ADMINISTRATION OF CATECHESIS AND CIVILIZATION OF THE INDIANS" IN THE PROVINCE OF BAHIA (1836-1887): BETWEEN CIVILIZATION AND LAND ISSUE}

Abstract: In the perspective of the insertion of the indigenous in society, this article investigates the administration of catechesis and civilization of Indians in the province of Bahia (18361887), based on the guidelines and application of Provincial Decree No. 32 of 1836 and Imperial Decree No. 426 of 1845 . Through a historical-descriptive approach, based mainly on primary sources - manuscript documents (letters, reports, correspondence) from the Public Archives of the State of Bahia (APEB) and edited documents (laws and reports) - as well as a select bibliography, seeks to confront and dialogue mainly the archival documentation of the various authors involved directly or indirectly in the process of catechesis and civilization of the Indians. The following results were evident: the Regulation of 1836 had little applicability since it did not give useful guidelines and had insufficient catechesis agents; Indians' Regulation of catechesis and civilization of 1845 had a partial application for lack of economic resources, and part of its anachronistic orientations concerning the reality of the old villages and towns of the Indians and discredited by the public authorities towards this type of public service; the Regulation of 1845 did not promote the foundation of new settlements, and the appointment of local directors for the old settlements further aggravated the conflicts over land ownership and contributed to the process of usurpation of the Indians' lands.

Keywords: Catechesis and Civilization. Indian villages. Indigenous resistance. Indigenous land. Bahia.

\section{Introdução}

Este estudo busca examinar a administração de "catequese e civilização dos índios"” na província da Bahia entre 1836 e 1887, a partir das orientações e aplicação do Decreto provincial $\mathrm{n}^{\circ} 32$, de 1836 e do Decreto imperial $\mathrm{n}^{\circ} 426$, de 1845 , que estabeleceu o Regulamento de

\footnotetext{
${ }^{2}$ A documentação de arquivo consulta para este trabalho utiliza o vocábulo "índio" para se referir aos povos originários. Ao longo deste estudo, utilizaremos as palavras indígena ou povos originários e será mantido o vocábulo "índio" somente nas expressões típicas da documentação de arquivo e da literatura especializada ["vilas de índios", "catequese e civilização dos índios", "Diretório dos Índios" e "Diretor Geral dos Índios"] e nas citações diretas.
} 
catequese e civilização dos índios. No período imperial brasileiro (1822-1889), a catequese e civilização dos índios era tida como um âmbito do serviço público e englobava todos os negócios relativos à integração dos povos originários na sociedade. Como já indica o binômio catequese e civilização, no período imperial brasileiro, assim como no período colonial, o poder temporal (do Estado) e o poder espiritual (da Igreja Católica) colaboravam reciprocamente na tarefa de assimilação cultural e religiosa dos povos nativos considerados selvagens e infiéis.

Em termos metodológico, a pesquisa se caracteriza por uma abordagem históricodescritiva, baseada fundamentalmente em fontes primárias, a saber, documentos manuscritos (ofícios, relatórios, correspondências) encontrados no Arquivo Público do Estado da Bahia (APEB) e documentos editados (coleção das Leis do Império $^{3}$ e relatórios dos Presidentes da província da Bahia $^{4}$ ), assim como em uma seleta bibliografia. Na abordagem ao tema, buscouse colocar em diálogo e confronto principalmente a documentação de arquivo dos diversos autores envolvidos direto ou indiretamente no processo de catequese e civilização dos índios.

No período colonial brasileiro (1500-1822), a política e as leis indigenistas buscaram a assimilação dos povos indígenas à sociedade vigente, isto é, ao modo de vida dos não indígenas. Esta tônica também continuou no período imperial brasileiro. Neste período, principalmente a partir de 1840, a política, as leis e os projetos civilizatórios em relação aos indígenas devem ser inseridos no contexto de transformação social pelo qual passava o Brasil por causa, dentre outros motivos, da urgente necessidade de mão-de-obra, agravada pela proibição do tráfico negreiro, e daí a precisão de aproveitar os "braços ociosos dos indígenas" e por causa da expansão da colonização nas zonas interioranas o que resultava em conflitos entre colonos e indígenas, e daí a exigência de apaziguar os povos originários considerados selvagens, reduzindo-os ao seio da sociedade. (CAMARA, 1851, p. 29-30; ARAÚJO, 1854, p. 26-27; PARAÍSO, 2000, p. 131).

Vale ressaltar que durante o século XIX na província da Bahia houve muitos aldeamentos e vilas de índios, muitos dos quais foram fundados nos séculos precedentes e outros durante este mesmo século. Neste contexto, falou-se de antigos aldeamentos e de vilas de índios, com habitantes considerados já civilizados, domésticos ou mansos e de novos aldeamentos com habitantes classificados como selvagens, semisselvagens, bravios ou catecúmenos.

\footnotetext{
3 Disponíveis na Biblioteca Digital da Câmara dos Deputados: https://bd.camara.leg.br/bd/handle/bdcamara/18353.

${ }^{4}$ Disponíveis em Center for Research Libraries: $\underline{\text { https://clck.ru/T67t4. }}$
} 
A documentação de arquivo consultada utiliza as palavras aldeia, aldeamento e missão como sinônimos. Estes vocábulos são utilizados para indicar os lugares criados para concentrar e manter os indígenas considerados selvagens e facilitar sua catequização e "civilização". A denominação do lugar como missão está a indicar que o estabelecimento era administrado por um missionário. Neste trabalho adotamos o vocábulo aldeamento por entender que é o que melhor expressa a atividade de concentração e manutenção dos indígenas em um determinado e circunscrito lugar com o objetivo de catequizá-los e civilizá-los e por compreender que o vocábulo aldeia expressa melhor o lugar natural dos povos originários. Porém, mantemos a palavra aldeia nas citações diretas.

A documentação de arquivo consultada utiliza o termo "vila de índios" para se referir aos povoados surgidos de aldeamentos fundados ao longo dos séculos XVI e XVIII e que no contexto da reforma promovida pelo "Diretório dos Índios", a partir de 1758, foram elevados à categoria de vila por terem um bom progresso civil e religioso. Isto é, do ponto de vista civil, muitos antigos aldeamentos foram elevados à categoria de vilas e passaram a ser governadas pelas respectivas Câmaras Municipais e, do ponto de vista religioso, passaram da categoria de missão (administrada por missionários) à freguesia (administradas pelos párocos). Eram denominadas "de índios" porque a população indígena nestes lugares era majoritária. (MARCIS, 2013, 187-247). Ao longo deste trabalho, manteremos a expressão "vila de índios" para expressar essa realidade.

Até 1835, por falta de um regulamento geral que orientasse os trabalhos de catequese e civilização dos índios, os aldeamentos existentes na província da Bahia foram orientados pelos resquícios permanecidos do revogado Diretório dos Índios de 1758. Para os aldeamentos continuou-se a nomear diretores para dirigir os indígenas e incitá-los ao trabalho. Nestas localidades, os diretores também exerciam o cargo de Escrivão. Além disso, eles eram encarregados de ensinar as primeiras letras e a doutrina cristã aos meninos, serviço que exerciam a pagamento, como por exemplo, em 1828, o diretor da vila de Soure recebia $80 \$ 000$ (oitenta mil réis) anuais e o da vila de Pombal, em 1829, recebia $60 \$ 000$ (sessenta mil réis). (CÂMARA MUNICIPAL DE SOURE, 1828; CÂMARA MUNICIPAL DE POMBAL, 1829).

Na documentação consultada para este estudo, os dados sobre os aldeamentos e vilas de índios existentes na província da Bahia, o número dos habitantes e o estado varia de acordo com as imprecisas informações que as autoridades públicas tinham a disposição.

Em 1830, a Comissão nomeada para dar um parecer sobre a criação de escolas na província da Bahia, em conformidade com lei de 15 de outubro de 1827, denominou 13 localidades como vilas de índios: Pedra Branca, Mirandela, Pombal, Soure, Olivença, Barcelos, 
Santarém, Alcobaça, Vila Verde, Viçosa, Francoso, Prado e São José de Porto Alegre (Mucuri). (ATAS DAS SESSÕES, 1830, Livro 199, p. 1-10).

Segundo esta Comissão, das 13 vilas de índios existentes, apenas em 6 havia uma escola de primeiras letras, a saber: Pedra Branca, Mirandela, Pombal, Soure, Santarém e Alcobaça. A Comissão informou que em todas estas vilas havia um diretor, encarregado de ensinar as primeiras letras às crianças, mas que via como necessária a criação de escolas em cada uma das ditas vilas, porque o exercício de escrivão era incompatível como o do magistério. (ATAS DAS SESSÕES, 1830, Livro 199, 1-10).

$\mathrm{Na}$ realidade, os diretores pouco faziam em benefício dos indígenas. As reclamações em relação ao desempenho destes funcionários são registradas com frequência na documentação. Em janeiro de 1829, a Câmara Municipal de Vila Verde falava da existência na vila de 60 meninos, "criados quase à lei da natureza", sem educação civil e religiosa por causa da inconstância dos escrivães-diretores. (CÂMARA DE VILA VERDE, 1829). No mesmo ano a Câmara Municipal de Valença, se referindo ao aldeamento de São Fidelis, informava que:

[...] os Indios vivião athé vagabundos, e sem ter quem os eduquem havendo tantas Leis, que os favorecessem e protegem [...] Esta Aldâe tem tido Directores, sem serem pagos, os quais em lugar de educarem os Indios os tornavão como seus Escravos, obrigando-os a descer madeiras pelos rios para si e para particulares; o antecessor do presente morava na Villa [de Valença], e raras vezes hia a Aldêa de sua direção, e o presente hé nimiamente ignorantes: ora parece que os Indios estão classificados na ordem dos cidadãos, que fazem parte da sociedade, e para entrarem dignamente n'ella hé necessário que tenhão luzes, motivo que igualmente nos conduz á respeitável Presença de V. Exa, afim de mandar para a dita Aldêa hum Mestre de primeiras Letras, que ao mesmo tempo sirva de Director com hum ordenado pago pela Fazenda. CÂMARA MUNICIPAL DE VALENÇA, 1829).

Com a primeira lei orçamentária provincial n 27, de 23 de junho de 1835 (COLEÇÃO DE LEIS E RESOLUÇÕES DA ASSEMBLÉIA LEGISLATIVA DA BAHIA, 1835-1838, p.74-87), não foi mais designada quantia para pagamento dos diretores de indígenas, por isso aqueles que exerciam por pagamento, deixaram formalmente de exercer as funções de diretores. A figura do diretor leigo e não religioso foi reproposta no Decreto provincial $n^{\circ} 32$ de 5 de março de 1836, mas nomeado pelo missionário ou pároco e caso este tivesse mais de um aldeamento sob sua inspeção. Já o Regulamento de 1845 irá privilegiar a administração do diretor leigo, como veremos ao longo deste estudo.

\section{Decreto provincial $n^{\circ} 32$ de 5 de março de 1836}


Até 1834, os negócios concernentes à catequese e civilização dos índios eram de competência do Governo imperial brasileiro. O Ato Adicional à Legislação de 1834, autorizou as províncias do Império a legislar sobre as questões indígenas. Procurando regular este âmbito do serviço público, a Assembleia Legislativa da Bahia promulgou o decreto $\mathrm{n}^{\circ} 32$, de 5 de março de 1836. (LEIS E RESOLUÇÕES DA ASSEMBLÉIA LEGISLATIVA DA PROVÍNCIA DA BAHIA, 1836, p. 76r-77v).

O primeiro artigo do decreto $\mathrm{n}^{\circ} 32$ determinou que o Governo Provincial proporcionasse a quantia que julgasse necessária para a subsistência dos missionários-párocos seculares ou regulares, brasileiros ou estrangeiros que se aplicassem na civilização e catequese dos indígenas. Não se mencionou qual seria a quantia, mas na discussão sugeriu-se que a côngrua fosse de 300\$000 (trezentos mil réis) anuais. Quanto aos aldeamentos, deveriam ser fundados com 50 ou mais famílias de indígenas. Falou-se também de premiar os missionários que se distinguissem por zelo apostólico na civilização dos povos originários. (LEIS APROVADAS PELA ASSEMBLÉIA LEGISLATIVA PROVINCIAL, 1836, p. 76r-77v; ATAS DAS SESSÕES, 1836a p. 18v, ATAS DAS SESSÕES, 1836b, p. 21r-22r).

A partir de 1836, portanto, a cada ano a Assembleia Legislativa Provincial passou a orçar e aprovar a quantia a ser gasta com a catequese e civilização dos índios. Ao longo dos anos tais verbas foram sempre tidas como insuficientes para atender as necessidades (BARÃO DE SÃO LOURENÇO, 1869, p. 72; HENRIQUES, 1872, p. 144-145). Esta verba era designada para o pagamento das côngruas e viagens dos missionários; para compras de materiais religiosos, instrumentos agrários, roupas, alimentos, dádivas e outros objetos que se julgassem necessários aos aldeados. (LEIS APROVADAS PELA ASSEMBLÉIA LEGISLATIVA PROVINCIAL, 1836, p. 76r-77v, 87r-87v, 105r-106r; LEIS APROVADAS PELA ASSEMBLÉIA LEGISLATIVA PROVINCIAL, 1840-1846, p. 134v; LEIS APROVADAS PELA ASSEMBLÉIA LEGISLATIVA PROVINCIAL, 1846-1850, p. 47r; LEIS APROVADAS PELA ASSEMBLÉIA LEGISLATIVA PROVINCIAL, 1850-1856, p. 16v).

$\mathrm{O}$ segundo artigo do decreto $\mathrm{n}^{\circ} 32$ determinou que o missionário que tivesse mais de um aldeamento sob a sua inspeção poderia nomear um diretor para aquele onde não residia e decretou que o Governo pagasse uma gratificação para o diretor; estabeleceu que nem os Juízes de Paz e nem os Vereadores poderiam ser diretores. Na discussão, se pleiteou que fossem pagos $300 \$ 000$ (trezentos mil réis) de gratificação aos diretores (LEIS APROVADAS PELA ASSEMBLÉIA LEGISLATIVA PROVINCIAL, 1836, p. 76r-77v; ATAS DAS SESSÕES, 1836b, p. 21r-22r; ATAS DAS SESSÕES, 1836c, p. 38r-38v). Dos dois primeiros artigos, 
ficava claro que a figura proeminente no plano de civilização dos indígenas era o missionáriopároco.

O terceiro artigo do decreto $n^{\circ} 32$ definiu a tarefa dos agentes da civilização: manter a ordem entre os indígenas, excitá-los ao trabalho e ensinar a mocidade a ler e escrever, enquanto não houvesse o magistério público. Na discussão também falou-se da competência do missionário e diretor de nomear entre os indígenas mais civilizados os agentes subalternos, assim como a competência de receber, arrecadar e distribuir os dinheiros e terras para a subsistência e aumento da empresa da diretoria. Ou seja, ele tinha em mão a administração espiritual e temporal dos aldeamentos. (ATAS DAS SESSÕES, 1836b, p. 21r-22r; LEIS APROVADAS PELA ASSEMBLÉIA LEGISLATIVA PROVINCIAL, 1836, p. 76r-77v.).

$\mathrm{O}$ quarto artigo do decreto $\mathrm{n}^{\circ} 32$ versou sobre questão de terras: para os novos aldeamentos que se fundassem com trinta famílias, se daria um quarto de légua em quadro de terra (1.650 metros $)^{5}$ como patrimônio e usufruto dos nativos; para os com mais de trinta famílias se daria meia légua em quadro (3.300 metros) y para os com mais de cento e vinte famílias se estabeleceria uma légua em quadro (6.600 metros). Já para os aldeamentos existentes sem patrimônio se demarcaria e aqueles que o tivessem, continuariam a conservá-lo, cuidando os diretores e missionários para que não fossem invalidadas as terras e possuídas ilegalmente (LEIS APROVADAS PELA ASSEMBLÉIA LEGISLATIVA PROVINCIAL. 1836, p. 76v-77r).

Medir e demarcar as terras onde se colocavam os aldeamentos era uma prática desde os tempos coloniais. Segundo o Alvará, de 23 de novembro de 1700, era doada a cada aldeamentomissão uma légua de terra em quadro para sustento dos indígenas e missionários. (FERREIRA, 1827). Essas terras formavam o patrimônio dos aldeados. Mas na província da Bahia, a quantidade de terras dos antigos aldeamentos e vilas variava de lugar para lugar. A maior parte tinha uma ou meia légua em quadro, mas algumas vilas havia até mais, como eram os casos das vilas de Abrantes, com duas léguas, e de Santo Antônio de Nazaré, com entre dez a quatorze léguas. (DORIA, 1860a).

$\mathrm{O}$ quinto artigo do decreto $\mathrm{n}^{\circ} 32$ definiu que a verba votada para a catequese fosse utilizada para as despesas com o culto religioso (côngrua do missionário e objetos religiosos) e com as necessidades dos indígenas (instrumentos agrários, alimentação, roupa etc.). (LEIS

\footnotetext{
${ }^{5}$ Segundo Sheila Brasileiro, a légua de terra em quadra era obtida traçando-se um raio de 1 légua (6.600 metros) do centro da aldeia, ou seja, da igreja em direção aos oito pontos cardeais e colaterais. Ela correspondia a um octógono regular de 12.320 hectares. (BRASILEIRO, 1999, p. 73-74).
} 
APROVADAS PELA ASSEMBLÉIA LEGISLATIVA PROVINCIAL, 1836, p. 77r; ATAS DAS SESSÕES, 1836c, p. 38r-38v).

O sexto artigo do decreto $n^{\circ} 32$ exigiu que os missionários e diretores prestassem anualmente conta das despesas ao Governo Provincial por intermédio dos Juízes de Direito. E o sétimo artigo deliberou que o Governo Provincial orçaria anualmente as despesas necessárias para a catequese e civilização dos índios. (LEIS APROVADAS PELA ASSEMBLÉIA LEGISLATIVA PROVINCIAL, 1836, p. 77r-77v; ATAS DAS SESSÕES, 1836c, p. 38r-38v).

O decreto provincial já nascia com um grave defeito: faltavam os executores principais do decreto, a saber, os missionários-párocos católicos seculares ou regulares, brasileiros ou estrangeiros. Uma das características da Igreja no Brasil do século XIX foi a falta de clero, secular e regular, principalmente nas vastas regiões interioranas. Os jesuítas tinham sido expulsos do Brasil em 1759, deixando um grande vazio na catequização dos indígenas. As clássicas Ordens Religiosas presentes no Brasil desde o período colonial (Franciscanos, Beneditinos, Carmelitas, Oratorianos) estavam em grave decadência no século XIX. (VIEIRA, 2016, p. 171-176). A Ordem dos Frades Menores Capuchinhos foi a única que durante o século XIX manteve um significativo apostolado entre os povos originários ${ }^{6}$.

A solução mais rápida para a urgente necessidade de missionários, principalmente para os ditos indígenas selvagens do sul da província da Bahia, foi, portanto, autorizar a vinda de religiosos Capuchinhos da Itália. Em 1836, o arcebispo da Bahia, Romualdo Antônio de Seixas (1787-1860), ciente de tal aprovação exclamava:

Em tais circunstancias, só restava lançar mão dos meios até agora empregados, e abonados pela experiência, recorrendo a esse mesmo providente viveiro de fervorosos missionários, que há dado as mais longínquas regiões do mundo católico, assim como a esta Província, exemplaríssimos e infatigáveis obreiros evangélicos. (SEIXAS, 1836).

A partir de fevereiro de 1840, o Governo Imperial também passou a solicitar missionários Capuchinhos da Itália e, a partir de 1843, incumbiu oficialmente estes religiosos para os trabalhos entre os povos originários em todo o Brasil, chamando-os da Itália e financiando seus trabalhos. (Coelho, 1840; Collecção das Leis do Império do Brasil DE 1843, 1843, p. 25). Mas os religiosos que chegaram até o final do período imperial eram sempre insuficientes para atender as necessidades apostólicas. Entre 1845 e 1887, o número dos Capuchinhos no Brasil oscilou entre 40 e 57 religiosos e muitos deles não se dedicavam à catequese dos indígenas (GALVÃO, 1845, p. 19; Camara, 1851, p. 29; Alburquerque, 1870, p. 55-56; Ávola, 1886, ff. 169r-172r).

\footnotetext{
${ }^{6}$ Para a atividade dos Capuchinhos no Brasil ver REGNI, 1988.
} 
Por outro lado, o decreto $n^{\circ} 32$ não deu orientações concretas para a administração e organização interna dos aldeamentos. Em abril de 1839, o arcebispo Seixas escrevendo ao Presidente da província da Bahia sobre a importância de "chamar os índios ao grêmio da igreja e da vida social" (Seixas, 1839), observava que:

[...] para que se possa conseguir este feliz resultado, parece-me que muito conviria organizar um sistema ou regimento para essas missões, estabelecendo as regras mais convenientes para a boa administração das aldeias, se é que o luminoso Diretório de 3 de maio de 1757, confirmado por Alvará de 17 de agosto de 1758 , não preenche completamente estes fins, e sobre tudo obrigando os missionários e diretores a enviar todos os anos ao Governo, e ao bispo diocesano, um exato e circunstanciado relatório do estado das ditas missões e aldeias, do seu progresso ou decadência, número de batismos, gênero de trabalhos, a que se dedicam, e para que mostram mais aptidão. (Seixas, 1839).

É interessante ressaltar como o arcebispo Seixas ainda cita o Diretório dos Índios de 1757. Por um lado, isso significa que o supracitado Diretório ainda continuava ditando orientações para a civilização dos indígenas, não obstante fosse considerado insuficiente para a boa administração dos aldeamentos. Por outro lado, significa que o decreto $n^{\circ} 32$ não teve uma efetiva aplicação. A partir de 1845, as vagas orientações provinciais para a catequese e civilização dos índios foram substituídas pelas determinadas no Decreto ${ }^{\circ} 426$ do Governo Imperial.

\section{Decreto $n^{\circ}$ 426, de 24 de julho de 1845: Regulamento de catequese e civilização dos índios e sua aplicação na província da Bahia}

Desde o início do Império brasileiro discutiu-se sobre a necessidade de um plano geral que adotasse medidas amplas e duradouras e desse um impulso à catequese e civilização dos índios, que há muitos anos jazia em abandono (CUNHA, 1992, p. 10). Foi, pois, com este intuito que o Decreto $\mathrm{n}^{\circ} 426$, de 24 de julho de 1845, aprovou o Regulamento de catequese e civilização dos índios (COLLECÇÃO DAS LEIS DO IMPÉRIO DO BRASIL DE 1845, 1845, p. 86-96).

O primeiro artigo do Regulamento determinou que fosse nomeado pelo imperador um Diretor Geral de índios para cada província do Império. A eles competia estudar, do ponto de vista social, cultural, econômico e religioso, os povos indígenas presentes nas suas respectivas províncias, a fim de melhorar as condições dos aldeamentos já existentes e de promover e fundar novos onde fossem necessários. (Collecção das Leis do Império do Brasil de 1845, 1845 , p. 86-91). 
O segundo artigo do Regulamento estabeleceu que fosse nomeado pelos presidentes das províncias, sob a indicação do Diretor Geral dos índios, um diretor para cada aldeamento. Aos diretores locais ou parciais, pertencia tudo o que concernia à administração civil dos aldeamentos em colaboração com o Diretor Geral. (Collecção das Leis do Império do Brasil De 1845, 1845, p. 91-94).

O terceiro, quarto, quinto e o sétimo artigos, determinaram que fossem colocados um tesoureiro ou um almoxarife e um cirurgião nos aldeamentos, onde se fizesse necessário. (Collecção das Leis do Império do Brasil DE 1845, 1845, p. 94-95).

O sexto artigo decretou que se colocasse um missionário para cada novo aldeamento fundado e para as que estivessem em lugares remotos, com a competência de "instruir os índios nas máximas da religião, e ensinar-lhes a doutrina cristã" e ensinar-lhes a ler e a escrever sem empregar a força ou a violência, e servir-lhes de pároco até quando o aldeamento-missão não passasse a ser paróquia. (Collecção das Leis do Império do Brasil DE 1845, 1845, p. 85).

No Regulamento, o diretor leigo e não religioso-missionário detém a administração civil do aldeamento. Em consonância com o revogado Diretório dos Índios (1757-1798), este Regulamento excluiu os religiosos da administração temporal dos aldeamentos. A presença do missionário foi prevista para os novos aldeamentos fundados e para aquelas em lugares remotos. Nestes lugares, os missionários ficaram responsáveis pela educação religiosa, e onde não houvessem os professores, também pela educação civil. Mas em seu complexo, o Regulamento assume um sistema misto, onde práticas civis e religiosas deveriam adoperar-se juntas e em cooperação para a catequese e civilização dos índios.

O Regulamento adota a política da brandura no trato com os povos indígenas. Isso não significa que as práticas de violência deixassem de existir nos interiores. (Malheiro, 1866, p. 313). A prova disso está na Circular de 9 de agosto de 1845, expedida pelo Governo Geral, determinando que não se comprassem e nem escravizassem os filhos dos indígenas presos em expedições. (CUNHA, 1992, p. 199).

Se compararmos o Regulamento de 1845 com as práticas civilizatórias do período colonial, percebe-se que o Regulamento não traz quase nada de novidade no que concerne às estratégias adotadas para assimilar os indígenas à vida civilizada. O Regulamento adotou o mesmo sistema de aldeamento do passado, ou seja, a redução dos indígenas em um espaço circunscrito, onde práticas civis e religiosas deveriam civilizar e catequizar os 'selvagens'.

Na província da Bahia, entre 1846 e 1889, foram nomeados, segundo as disposições do primeiro artigo do Regulamento de 1845, sete Diretores Gerais de índios: Manoel Ignácio Lima, entre 1846 e 1849; Casemiro de Sena Madureira, entre 1850 e 1858; José Jacome Doria, entre 
1859 e 1862; Barão do Rio Vermelho, entre 1862 e 1870; Visconde de Sergimirim, entre 1870 e 1880; Barão do Rio Real, entre 1880 e 1887; e Visconde da Oliveira, entre 1887 e 1889. (DORIA, 1858, 1960b, 1862; VISCONDE de Sergimirim, 1870a).

O processo de aplicação do Regulamento foi muito lento e logo os problemas se mostraram evidentes. Uma das primeiras dificuldades que teve o Diretor Geral dos índios foi a de obter informações exatas sobre os aldeamentos existentes e sobre os povos originários ainda por aldearem. Mas, esse foi um obstáculo com o qual teve que lidar não só o primeiro Diretor Geral, mas todos àqueles que foram nomeados. (LIMA, 1847, 1848; Visconde de Sergimirim, 1874). A falta de informações era dificultada por causa da complexidade da realidade indígena, das enormes distâncias e péssimas vias de comunicação, e às vezes pela falta de preparação dos diretores parciais. Mas elas eram também obstadas e distorcidas de propósito pelos que tinham intenção de beneficiar-se com a situação de confusão.

Em fevereiro de 1847, Antônio Inácio de Azevedo, Presidente da província da Bahia, falando à Assembleia Legislativa Provincial, afirmava que ainda não era tempo de informar sobre os resultados produzidos pelo Regulamento de 1845. Para Azevedo, até aquele momento a aplicação do Regulamento tinha se limitado na nomeação do Diretor Geral dos índios, do qual se esperava resultados benéficos para os aldeados. Na opinião de Azevedo, as terras dos aldeamentos estavam sendo usurpadas pelos poderosos locais (Azevedo, 1847, p. 14).

As Câmaras e os Vigários que poderiam lembrar suas urgências, aquelas no temporal e estes no espiritual, são ás vezes quem lhes causa danos, pois alguns diretores de índios se queixão de que as Câmaras, outros que os Vigários, lhes tem usurpado suas terras sob diversos pretextos e nenhum benefício lhes fazem. Os Juízes de Órfãos com raríssimas excepções nada tem praticado, que redunde em proveito desta classe de indivíduos carecedores de todo o favor do Governo. (AZEVEDO, 1847, p. 14).

Em julho do mesmo ano, Manoel Ignácio Lima, Diretor Geral dos Índios, observava que o Regulamento de 1845 ainda não tinha dado os frutos desejados, porque era necessário muito tempo para remover os inveterados abusos. (LIMA, 1847).

[...] as rendas das (terras) que estão em arrendamento, são mesquinhas desproporcionadas e mal cobradas, e com dificuldade grande se poderá dar remédio, por que muitos terrenos estão ocupados com benfeitorias de Engenhos de açúcar, e outras de grande preço; que aos índios falta a mesma instrução primaria, que a nenhuma industrias se aplicam, e quase nenhuma lavoura fazem, e apenas se prestam a serviço de outrem mediante um pequeno estipendio. (LIMA, 1847).

Essas primeiras informações retratam a situação dos aldeamentos de antiga fundação e das vilas de índios: usurpação das terras e falta de instrução civil e religiosa. Para obstar as 
contínuas usurpações das terras dos indígenas, Lima pediu que elas fossem medidas. Nessa ocasião ele não soube informar quanto seriam os indígenas em regime de aldeamento, mas afirmava serem poucos, por causa do abandono dos aldeamentos, pelos limitados meios de subsistência e por falta de diretores virtuosos. (LIMA, 1847).

Desde os tempos do Diretório dos Índios de 1757, quando um aldeamento era elevado à categoria de vila, permitiu-se que a Câmara Municipal arrendasse parte das terras que os indígenas não usavam e aplicasse o produto arrecadado em benefício dos indígenas. Ao longo dos anos, as Câmaras Municipais foram sempre se apossando da administração de tais terrenos. Ademais, reagindo ao suposto isolamento que os jesuítas teriam mantido os aldeados, tal política indigenista passou a incrementar uma forte política de miscigenação que visava assimilar os povos originários fisicamente e socialmente. Uma das práticas para "misturar as raças", foi a de introduzir não indígenas nos aldeamentos, arrendando lotes de terras a particulares dentro do terreno dos aldeamentos. (MARCIS, 2013, p. 25). De consequência, durante o século XIX, a presença de não indígenas nas vilas e aldeamentos era uma realidade constante e conflituosa.

A preocupação pelas questões relacionadas às terras dos aldeamentos está bem presente no Regulamento de 1845 . Para os aldeamentos existentes, ficou determinado no artigo $1^{\circ} \S 4^{\circ}$ e $5^{\circ}$ que competia aos Diretores Gerais de Índios indagar acerca do modo como os indígenas estavam utilizando as terras dos aldeamentos, se elas estavam ocupadas por outras pessoas e sob que títulos e indicar ao Governo Imperial que destino dar às terras dos aldeamentos que tinham sido abandonados. (Collecção das Leis do Império do Brasil de 1845, 1845, p. 87).

Os artigos $1^{\circ}, \S 12^{\circ}, \S 13^{\circ}$ e $2^{\circ} \S 2^{\circ}$ do Regulamento de 1845 prescreveram três modos de utilização das terras dos aldeamentos: para o uso comum dos indígenas, para o uso particular dos indígenas e para ser arrendadas ${ }^{7}$. Competia ao Diretor Geral dos Índios determinar a porção de terra para as plantações em comum dos indígenas, a porção de terra para as plantações particulares dos indígenas, e a porção de terra que poderia ser arrendada por particulares não indígenas. As terras para arrendamento, reservada da porção que os indígenas não utilizavam, poderiam ser arrendadas por um período de três anos. (Collecção das Leis do Império do Brasil de 1845,1845 , p. 87-88).

\footnotetext{
${ }^{7}$ Arrendar expressa o ato de ceder a outra pessoa o usufruto de um bem por um certo preço e por um período. No século XIX, as terras dos aldeamentos podiam ser arrendadas, ou seja, podiam ser cedidas temporariamente mediante pagamento para o usufruto de particulares. Portanto, denomina-se rendeiro a pessoa que alugava um lote de terra dentro das terras de um determinado aldeamento. (CUNHA, 1992, p. 144-145).
} 
A administração dos bens dos indígenas era, portanto, de competência do Diretor Geral dos Índios, que se servia dos diretores dos aldeamentos para arrendar as terras, recolher os réditos e aplicá-los em benefício dos indígenas (art. 2, § $8^{\circ}$ ) como sustento, vestuário, curativo dos mais pobres, educação das crianças, concerto da capela e compra de utensílios religiosos necessários. (Collecção das Leis do Império do Brasil de 1845, 1845, p. 92).

No artigo $1^{\circ} \S 13$ do Regulamento de 1845 adverte-se sobre a necessidade de se fazer uma minuciosa investigação sobre o bom comportamento das pessoas que pretendiam obter as terras em arrendamento. Vale ressaltar que o motivo dessa advertência era justamente devido aos abusos cometidos pelos arrendatários. (Collecção das Leis do Império do Brasil de 1845, 1845, p. 92).

$\mathrm{O}$ artigo $1^{\circ} \S 15^{\circ}$ do Regulamento de 1845 determinou a concessão de terras separadas dos aldeamentos para aqueles indígenas que demonstrassem bom comportamento e satisfatório desenvolvimento industrial. A aquisição definitiva das terras se daria depois de doze anos de ininterruptas boas culturas. (Collecção das Leis do Império do Brasil de 1845, 1845, p. 88). Esta orientação, portanto, pressupõe a "civilização" dos indígenas.

$\mathrm{O}$ artigo $2^{\circ} \S 14^{\circ}$ do Regulamento de 1845 decretou que competia ao diretor dos aldeamentos promover a demarcação das terras dos aldeamentos. (Collecção das Leis do Império do Brasil de 1845, 1845, p. 93).

Vale ressaltar, portanto, que a prática de arrendamento de terras dos aldeamentos era uma prática em uso desde o século XVIII, utilizada com a finalidade de favorecer a miscigenação e arrecadar recursos para custear os gastos com os aldeados. Ao longo dos anos, esta prática constituiu-se um dos mecanismos no processo de usurpação das terras dos aldeamentos. O Regulamento de 1845 manteve a prática de arrendamento de terras dos aldeamentos.

Com a nomeação dos diretores para alguns antigos aldeamentos e vilas indígenas, segundo as orientações do Regulamento de 1845, veio à tona ainda mais o conflito concernente à administração e posse das terras que há anos estava se consumando nestes lugares. Na medida em que o Diretor Geral dos Índios ia nomeando os diretores para as vilas, onde as Câmaras Municipais administravam as terras, surgiam conflitos entre estas e aqueles, pois entrando em exercício do cargo, os diretores exigiam que lhe fossem entregues a administração das terras. Para as Câmaras Municipais, perder tal administração, significava ficar sem uma fonte de renda. Os conflitos foram verificados nas vilas de Santarém, Abrantes, Barcelos e na vila da Barra de Rio de Contas. (Abaixo-assinado dos Índios da vila de Santarém, 1846; Câmara Municipal de 
Santarém, 1846; Santos, 1850; Câmara municipal de Barcelos, 1851, 1869; Visconde de Sergimirim, 1873c).

Em alguns aldeamentos, os diretores nomeados também entraram em conflitos com os rendeiros das terras dos aldeamentos, pois estes se adoperavam para que as diretorias fossem obstaculizadas na sua administração para disporem das terras. Denúncias relativas à usurpação de terras se verificaram no aldeamento Saco dos Tapuias e nas vilas de Soure, Bom Jesus da Glória, Santo Antônio de Nazaré e Aricobé. Enfim, em todos estes lugares supracitados, quem em maior ou menor proporção, surgiram conflitos, acusações em relação à administração e posse das terras. (Câmara municipal de Jacobina, 1851; Madureira, 1854d; Câmara municipal de Nazareth, 1869).

Outro obstáculo não indiferente na aplicação do Regulamento de 1845 foi a falta de pessoas idôneas para os cargos de diretores dos aldeamentos. Quase todos os nomeados eram tidos como habilitados das qualidades para exercer o cargo, mas logo os problemas apareciam: não arrecadavam bem as rendas das terras, ou se o faziam, não aplicavam em benefício dos indígenas e não prestavam conta ao Diretor Geral dos Índios; em vez de tutelar as terras eram os primeiros a usurpá-las em conluio com os arrendatários. Não faltaram os diretores que procuraram exercer bem o cargo, mas tanto estes como aqueles que se adoperavam mais por interesse próprio, geralmente se envolviam em um emaranhado de intrigas com as autoridades locais e rendeiros que resultava em uma troca de acusações, que confundia as autoridades provinciais na capital. (Câmara Municipal de Santarém, 1846; Câmara municipal de Barcelos, 1851; Câmara municipal de Nazareth, 1869).

Ao longo do século XIX, nota-se uma diminuição e dispersão dos povos originários das vilas e um aumento da população não indígena. Essa tendência se intensificou ainda mais depois da Lei de $1^{\circ}$ de outubro de 1828 que dava "nova forma às Câmaras Municipais", com a qual os indígenas foram afastados da participação do corpo administrativo por não serem considerados idôneos (Collecção das Leis do Império do Brasil de 1828, 1878, p.74). Diante deste processo de exclusão houve resistência indígena. Citamos, como exemplo, a vila de Mirandela, onde em 1833, segundo a Câmara Municipal, nos últimos anos estava concorrendo para a vila alguns "brasileiros" (não indígenas), mas que os indígenas estavam se opondo à construção de casas e à execução das novas leis. (Câmara Municipal de Mirandela, 1833a; Junior, 1833; Resposta à representação dos índios, 1833). Esta atitude dos indígenas de Mirandela era uma forma de resistir à exclusão da participação no corpo administrativo. $\mathrm{O}$ aumento da população não indígena era visto como uma ameaça aos interesses dos indígenas. 
Vale ressaltar que os indígenas dos antigos aldeamentos e vilas, não viviam em estrito regime de aldeamento. Já estavam “sedentarizados”. Cada família vivia em seu pequeno sítio, situado dentro do terreno considerado patrimônio dos indígenas. Mas por causa das perseguições, algumas famílias migravam e vagavam à procura de terras. Alguns viviam das suas pequenas plantações de milho, feijão, mandioca, cana de açúcar, arroz, banana e da caça e da pesca; outros trabalhavam como diaristas para particulares por pequenos salários no corte e condução de madeira e também como vaqueiros. (Barberino, 1835; Câmara municipal da vila de Trancoso, 1849; Câmara municipal de Barcelos, 1849).

A maior parte das autoridades locais eram unânime em enfatizar que os indígenas só trabalhavam constrangidos pelas urgentes necessidades, por serem naturalmente inclinados à inércia, ou seja, preguiçosos. Nos municípios onde eles eram rotulados como bravos, suas incursões eram consideradas como a causa do pouco progresso da agricultura e do comércio. Nos lugares onde os indígenas eram tidos como domesticados, mansos e misturados a causa do pouco e tão almejado progresso foi também atribuída à indolência dos indígenas. (Câmara municipal de Barcelos, 1849a, 1849b; CÂMARA MUNICIPAL DE SOURE, 1849; Lobão, 1860).

As informações - bastante registradas nas correspondências e relatórios das autoridades locais - de que os indígenas não trabalhavam, que eram inertes e preguiçosos devem ser vistas também como atitudes e estratégias de resistência dos indígenas frente à exploração. Tais informações devem ser inseridas no contexto das disputas e conflitos de interesses, que envolvia, principalmente, a posse da terra. Nesse contexto, buscava-se sublinhar que os indígenas não usufruíam das terras de seu patrimônio para justificar que elas fossem aforradas ou invadidas.

Para evitar as usurpações das terras, alguns indígenas e algumas autoridades como os Juízes de Paz pediram ao Governo provincial que as terras dos aldeamentos fossem medidas. Em 1847, o Diretor Geral dos índios também havia proposto esta mesma medida. No início de 1848, o Governo Provincial ordenou aos Juízes municipais que demarcasse as terras para que no futuro se evitasse contestações judiciais e garantisse de modo permanente o patrimônio dos indígenas. (Magalhães, 1848, p. 41-42). Mas geralmente este tipo de ordem ficava sem execução.

A partir da Lei de terras $\mathrm{N}^{\circ} 601$ de 18 de setembro de 1850 e do Decreto 1.318 de 30 de janeiro de 1854, expedidos pelo Governo Imperial (Collecção das Leis do Império do Brasil de 1854, p. 9-28; Collecção das Leis do Império do Brasil de 1850, p. 307-313), a Repartição Especial das Terras Públicas da Bahia ordenou a demarcação das terras dos aldeamentos da 
província. Esta ordem enfrentou diversas dificuldades para ser executadas, como a falta de documento que comprovasse a quantidade de terras dos antigos aldeamentos e vilas de índios, o desinteresse das autoridades locais e a ineficiência do Governo Provincial, principalmente por falta de meios econômicos para executar as demarcações. De consequência, pouco se executou

No jogo de interesse e conflitos entre autoridades locais (vereadores, juízes, delegados, párocos), rendeiros e diretores, os indígenas ditos civilizados mantinham atitudes ativas. Eles recorriam à violência para vingar as agressões recebidas e/ou exigiam das autoridades locais e provinciais que seus interesses fossem garantidos. Um exemplo ocorreu na vila do Prado em 1832, quando um grupo de indígenas aliados com alguns "brasileiros natos", chefiado pelo indígena Manoel Ribeiro, ameaçaram invadir a vila para soltar o indígena João e expulsar o Juiz de Paz Manoel José de Souza. Segundo os vereadores, o motivo pelo qual eles exigiram a retirada do juiz era por ser o juiz "brasileiro adotivo", ou seja, português. Essa pressão levou, de fato, à demissão do juiz que foi substituído interinamente por Francisco Antônio Fontoura, “brasileiro nato". (Câmara municipal de Prado, 1831, 1832).

Outros indígenas para reivindicarem seus direitos apelavam às autoridades provinciais, como ao Presidente da província e ao Diretor Geral dos Índios e até mesmo ao Imperador. Em 1887, três indígenas de Mirandela foram à corte queixar-se ao Governo Imperial contra os usurpadores de suas terras. O mesmo fizera oito indígenas do aldeamento de Aricobé. (Mello, 1887, p. 157). Eles apresentavam-se principalmente às autoridades pessoalmente e, às vezes, através de cartas, onde geralmente pediam proteção para si e suas terras, a nomeação de um diretor ou a demissão daquele em função, e a nomeação de um capelão que lhes administrassem gratuitamente os sacramentos. (Resposta à representação dos índios, 1833; Abaixo-assinado dos Índios da Aldeia de S. Fidelis, 1835; Santana, 1884).

A partir de 1850, a solução invocada por alguns Juízes de Direito e Municipais para os conflitos de terras nos aldeamentos e vilas, foi a indicada pela Decisão $n^{\circ} 92$, de 21 de outubro de 1850 do Governo Geral (Cunha, 1992, p. 213-214), que estabeleceu que os aldeamentos onde os indígenas já vivessem dispersos e "confundidos na massa da população civilizada", fossem considerados oficialmente extintos, medidas as terras e distribuídos lotes aos indígenas que ainda existiam e incorporasse o restante das terras como devolutas aos não indígenas. (Nunes, 1851; Ribeiro, 1853; Viana, 1869). Em 1851, o Diretor Geral dos índios aconselhava que o restante das terras fosse vendido em hasta pública, e que enquanto essa medida não fosse

\footnotetext{
${ }^{8}$ Para as questões relativas aos registros e medição das terras, ver APEB, Repartição Especial das Terras Públicas. Registros de Correspondência expedida (1859-1860), Seção Colonial/Provincial, Maço N$^{\circ} 7030$ e Terras Públicas (1836-1858) Seção Colonial/Provincial, Maço № 6508.
} 
aplicada, seria conveniente que as rendas dos aldeamentos fossem arrecadadas pela Fazenda Pública. (Madureira, 1851).

Saber com exatidão a quantidade e os lugares dos terrenos de alguns aldeamentos não era uma tarefa fácil. Primeiro, porque os Alvarás ou Títulos pelos quais tinham sido doadas as terras já não existiam. Segundo, porque os marcos das antigas demarcações tinham desaparecido ou, em alguns casos, tinham sido removidos de propósito. Portanto, se sabia mais por tradição oral quanto era a quantidade e por onde passavam os limites das terras dos aldeamentos. (DORIA, 1860c; JOSÉ, 1861).

Nas vilas onde as Câmaras Municipais estavam administrando o antigo patrimônio dos indígenas e onde a nomeação dos diretores havia suscitado conflitos, a decisão da Assembleia Legislativa Provincial foi a de autorizar que estas continuassem na administração das terras, como fez, em 1848, em relação à vila de Santarém: (Vasconcellos, 1848b; Câmara municipal de Santarém, 1848).

Como as terras foram originariamente dadas aos índios para nelas estabelecerem plantações para sua subsistência, é sem questão que se deve assignar a cada um a porção que lhes seja necessária para cultivar; e se houverem sobras, deverão estas ficar sob a administração da Câmara para arrendar, e aplicar a seu produto as despesas do Município, donde também resulta utilidade aos índios, que não devem desfrutar em ócio o rendimento das terras, que não cultivam. (CÂMARA MUNICIPAL DE SANTARÉM, 1848).

Esta decisão resolvia a questão entre a Câmara e o diretor, mas os conflitos relativos à posse das terras continuaram entre a Câmara, os indígenas e os rendeiros.

A partir, portanto, de 1851, se delinearam duas exigências: declarar extinto, senão todos, pelo menos a maior parte dos antigos aldeamentos da província da Bahia e manter os do sul da província e fundar outros novos. Casemiro de Sena Madureira, Diretor Geral dos Índios, procurando vencer os obstáculos inerentes à sua administração, propôs que todas os aldeamentos da província fossem extintos, exceto os quatro existentes na margem do rio Pardo. Para Madureira, o cargo de diretores nos lugares onde os povos originários eram civilizados e viviam dispersos era inútil. O motivo, portanto, para extinção dos antigos aldeamentos, segundo Madureira, era que os indígenas nesses lugares já estavam civilizados, assimilados e vivendo dispersos. (MADUREIRA, 1851).

Madureira esperava que a Diretoria Geral dos Índios ficasse limitada somente às Comarcas de Ilhéus, Porto Seguro e Caravelas, onde unicamente os indígenas precisavam de catequese, de inspeção e proteção do Governo:

A primeira necessidade dos índios, ainda não civilizados, que há pouco se aldearam na Comarca dos Ilhéus, é a conservação de Missionários que os 
dirijam na catequese, e a dos selvagens nas matas das Comarcas de Caravelas e Porto Seguro, é sem contradição a remessa de capuchinhos, que vão ás margens do Mucuri, do Prado, Belmonte ou Jequitinhonha, e do Rio Pardo chamá-los à civilização, para o que tenho pedido a V. Exa. providencias, por não haverem no Hospício (Convento) da Piedade desta cidade mais alguns (capuchinhos) que se prestem a requisição do Exmo. Presidente da Província [...]. (MADUREIRA, 1851).

Nos novos aldeamentos fundados no sul da província da Bahia procurou-se colocar como diretor um missionário Capuchinho. Era comum a opinião de que os melhores diretores para os indígenas tidos como selvagens fossem os missionários (MADUREIRA, 1850; Wanderley, 1853, p. 36). Mas os Capuchinhos também exerceram a função de diretor de índios em alguns antigos aldeamentos onde os conflitos eram constantes, como em Pedra Branca (RIBEIRO, 2020, p. 150-158), e em alguns aldeamentos onde os indígenas eram considerados como semisselvagens, como em São Pedro de Alcântara (REGNI, 1988, p. 328-333).

Em março de 1853, João Maurício Wanderley (1815-1889), Presidente da província da Bahia, também reconhecia que o atual sistema aplicado aos povos originários "fundidos na sociedade", não só não era necessário, como era até prejudicial aos indígenas, pois acabava por perpetuá-los num sistema de tutoria que não os integravam na sociedade. Para ele, o Regulamento de 1845 tinha que ser aplicado somente nos aldeamentos de catecúmenos. Ele concluía que o Regulamento 1845 também não tinha contribuído para a civilização dos indígenas selvagens. (WANDERLEY, 1853, p. 34-35).

Em 1855, dos 31 lugares listados pelo Diretor Geral dos Índios, 11 eram vilas de índios e 14 antigos aldeamentos. Aqueles de recente fundação, ou seja, fundados depois de 1818, estavam nos municípios de Ilhéus e Vitória da Conquista, a saber, São Pedro de Alcântara, Catulé, Barra do Salgado e Santo Antônio da Cruz. Do quadro abaixo, fica claro que a maior parte dos indígenas que vivia nestas localidades eram considerados civilizados, enquanto os catecúmenos (em 'processo civilizatório') e os selvagens por aldear se encontravam somente no sul da província. (WANDERLEY, 1855, p. 20-21). 


\begin{tabular}{|c|c|c|c|}
\hline \multicolumn{4}{|c|}{$\begin{array}{l}\text { Quadro dos aldeamentos e vilas de índios existentes na província da Bahia em } \\
1855\end{array}$} \\
\hline \multicolumn{4}{|c|}{\begin{tabular}{|l|c|c|c|}
\multicolumn{4}{|c|}{1855} \\
Comarcas & Aldeamentos e vilas de & $\begin{array}{l}\text { Num. dos } \\
\text { indígenas }\end{array}$ & $\begin{array}{c}\text { Estado de } \\
\text { Civilização }\end{array}$ \\
\end{tabular}} \\
\hline $\begin{array}{l}\text { Rio S. } \\
\text { Francisco }\end{array}$ & 1. Aricobé & - & - Civilizados \\
\hline Monte Santo & $\begin{array}{l}\text { 2. Massacarás } \\
\text { 3. Rodellas }\end{array}$ & $\begin{array}{l}-150 \\
\cdot 140\end{array}$ & $\begin{array}{l}\text { - Idem } \\
\text { - Idem }\end{array}$ \\
\hline Jacobina & $\begin{array}{l}\text { 4. B. Jesus da Gloria } \\
\text { 5. N. Sra. do Sahy }\end{array}$ & $\begin{array}{l}\bullet \\
\bullet \\
\bullet\end{array} 6$ & $\begin{array}{l}\text { - Idem } \\
\text { - Idem }\end{array}$ \\
\hline Inhambupe & 6. Saco dos Tapuios & - 150 & - Idem \\
\hline Itapicuru & $\begin{array}{l}\text { 7. N. Sra. da Saúde } \\
\text { 8. Suore (vila) } \\
\text { 9. Pombal (vila) } \\
\text { 10. Mirandela (vila) }\end{array}$ & $\begin{array}{l}\text { - } 160 \\
\text { - } 520 \\
\text { - } 230 \\
\text { - } 540\end{array}$ & $\begin{array}{l}\text { - Idem } \\
\text { - Idem } \\
\text { - Idem } \\
\text { - Idem }\end{array}$ \\
\hline Nazareth & $\begin{array}{l}\text { 11. Santo Antônio } \\
\text { 12. Prazeres }\end{array}$ & $\begin{array}{l}\cdot 108 \\
\cdot 65\end{array}$ & $\begin{array}{l}\text { - Idem } \\
\text { - Idem }\end{array}$ \\
\hline Abrantes & $\begin{array}{l}\text { 13. Abrantes (vila) } \\
\text { 14. Massarandupió }\end{array}$ & $\begin{array}{l}\text { - } 230 \\
\text { - } 320\end{array}$ & $\begin{array}{l}\text { - Idem } \\
\text { - Idem }\end{array}$ \\
\hline Cachoeira & 15.Pedra Branca & - 200 & - Idem \\
\hline Camamu & $\begin{array}{l}\text { 16. Barcellos (vila) } \\
\text { 17.São Miguel }\end{array}$ & $\begin{array}{l}\cdot 200 \\
\text { - } 50\end{array}$ & $\begin{array}{l}\text { - Idem } \\
\text { - Idem }\end{array}$ \\
\hline Valença & $\begin{array}{l}\text { 18. Santarém (vila) } \\
\text { 19. São Fidelis } \\
\text { 20. Santa Rosa }\end{array}$ & $\begin{array}{l}-70 \\
\cdot 170 \\
\cdot 95\end{array}$ & $\begin{array}{l}\text { - Idem } \\
\text { - Idem } \\
\text { - Idem }\end{array}$ \\
\hline Porto Seguro & $\begin{array}{l}\text { 21. Vila Verde (vila) } \\
\text { 22. Santa Cruz } \\
\text { 23. Trancoso (vila) }\end{array}$ & $\begin{array}{l}\cdot 50 \\
-40 \\
\cdot 500\end{array}$ & $\begin{array}{l}\text { - Idem } \\
\text { - Idem } \\
\text { - Idem }\end{array}$ \\
\hline Ilhéus & $\begin{array}{l}\text { 24. Olivença (vila) } \\
\text { 25. Catulé } \\
\text { 26. Barra do Salgado } \\
\text { 27. S. Pedro de Alcântara } \\
\text { 28. Sto. Antônio da Cruz }\end{array}$ & $\begin{array}{l}\text { - } 200 \\
\text { - } 106 \\
\text { - } 125 \\
\text { - } 128 \\
\text { - } 30\end{array}$ & $\begin{array}{l}\text { - Idem } \\
\text { - Catecúmenos } \\
\text { - Idem } \\
\text { - Idem } \\
\text { - Idem }\end{array}$ \\
\hline Caravelas & $\begin{array}{l}\text { 29.Peruipe } \\
\text { 30.Prado (vila) } \\
\text { 31.S. José do Mucuri (vila) }\end{array}$ & $\begin{array}{l}\text { - } 40 \\
\text { - } 140 \\
\text { - } 300\end{array}$ & $\begin{array}{l}\text { - Idem } \\
\text { - Idem } \\
\text { - Civilizados }\end{array}$ \\
\hline
\end{tabular}

Fonte: Elaboração do autor, com base em: WANDERLEY, 1855. Anexo Quadro $n^{\circ} 7$ dos aldeamentos e vilas de índios da província da Bahia. 


\begin{tabular}{|c|c|c|c|}
\hline \multicolumn{4}{|c|}{ Indígenas aldeados e habitantes das vilas e antigos aldeamentos } \\
\hline Ano & Civilizados & Catecúmenos & Total \\
\hline $\mathbf{1 8 5 4}$ & 4.695 & 313 & 5.008 \\
\hline $\mathbf{1 8 5 5}$ & 4.609 & 569 & 5.178 \\
\hline $\mathbf{1 8 5 6}$ & 4.600 & 380 & 4.980 \\
\hline $\mathbf{1 8 5 9}$ & - & - & 4.621 \\
\hline $\mathbf{1 8 6 0}$ & - & - & 5.579 \\
\hline
\end{tabular}

Fonte: Elaboração do autor, com base em: MADUREIRA, 1854a, 1854b, 1854c, 1855a; 1855b, 1855c, 1856; DORIA, 1860a.

Os dados sobre os aldeamentos e vilas de índios existentes e o número de seus habitantes coletados dos relatórios dos Diretores de Índios entre os anos de 1850 e 1860, devem ser considerados como aproximativos, já que esta Diretoria confeccionava seus relatórios baseados em informações não exatas e não atualizadas. (Madureira, 1856; Barreto, 1859, p. 12; DORIA, 1960a; Penna, 1860, p. 32-33).

Assim como o Diretor Geral dos Índios, Wanderley também era da opinião que a maior parte dos aldeamentos fosse extintos, conservando somente os de catecúmenos, como também aqueles que necessitassem de uma administração particular por causa das terras. Onde existiam as vilas, ele era do parecer que as ditas terras passassem a fazer parte do patrimônio das respectivas Câmaras. Para Wanderley, não era "possível nem útil que se conserve os descendentes dos índios em uma perpétua tutela que os mantem em lastimoso estado de inferioridade em relação a outros cidadãos da mesma condição e educação". (Wanderley, 1855, p. 21).

Na década de 1850, portanto, tanto o Diretor Geral dos índios como alguns Presidentes da província estavam de acordo acerca da necessidade de declarar extintos alguns aldeamentos e sobre a necessidade de manter e fundar outros no sul da província. Quanto à extinção dos antigos aldeamentos, geralmente pouco ou nada se fazia a respeito, e se continuará a nomear os diretores para esses aldeamentos, que de fato eram assim denominados por causa das terras, mas não porque os indígenas viviam em regime de aldeamento. (MADUREIRA, 1854a; DORIA, 1860b).

Nos anos seguintes, a realidade não será muito diferente. Em janeiro de 1860, José Jacome Doria, Diretor Geral dos Índios, observava que se o Governo Provincial resolvesse cuidar assiduamente da sorte dos indígenas, e consequentemente, do melhoramento da administração, deveria: 
depois de proceder as precisas indagações acerca do verdadeiro estado atual das aldeias, quer por meio de minuciosas informações das autoridades locais, quer pelo de comissões especiais que satisfatoriamente as prestem, deverá por hábeis empregados responsáveis a testa das mesmas, sem exclusão das que se dizem mais civilizadas, e ou dando por extintas aquelas que julgar no caso de seu inteiro aperfeiçoamento (do que por ora duvido) ou mesmo como menos necessita das de serem assim regidas, nomear-lhes quanto antes diretores, apenas no caráter de tesoureiros de maneira que não fique nunca alguma sem chefe que a reja, podendo somente assim reorganizar-se o serviço geral e relacionado, capaz de preencher os fins que se teve em vistas na expedição do citado Decreto-regulamento. (DORIA, 1860b).

Doria duvidava de que todos os aldeamentos de antiga fundação estivessem no caso de serem extintos. Para ele, era necessário nomear diretores apenas com caráter de tesoureiro até mesmo para aqueles indígenas que se diziam mais civilizados. Mas de sua proposta de nomeação de diretores apenas com caráter de tesoureiro, percebe-se que se procurava apenas administrar as terras dos aldeamentos.

Em 1874, Visconde de Sergimirim, Diretor Geral dos Índios, chamou a atenção sobre a necessidade de instrução para os indígenas. Para Sergimirim, no estado atual dos aldeamentos, com pequena diferença, os indígenas viviam a mesma vida que nas florestas: não recebiam nenhuma noção de civilização e estavam sendo vencidos pelos seus vícios e eram membros deteriorados que aumentavam o número dos habitantes, mas não dos cidadãos úteis ao país. (Visconde de Sergimirim, 1874).

No estado atual, segundo Sergimirim, se estava transformando os "inocentes índios" não em "cidadãos civilizados", mas em indivíduos deteriorados. Para ele, era urgente algumas providências: instituir escolas, pois a educação e a instrução bem dirigidas eram as maiores barreiras para a continuação da vida "meio selvagem" nos aldeamentos; prover instrumentos oratórios, instrumentos mecânicos e o ensino dos ofícios como ferreiro, carpinteiro e pedreiro àqueles que mostrassem aptidão; construir uma capela em cada aldeamento; fornecer boas sementes; e aumentar a verba para a catequese. Na opinião de Sergimirim, alguns aldeamentos deveriam ser reorganizados totalmente, já outros deveriam ser eliminados, sendo os terrenos medidos, demarcados e vendidos, reservando somente o necessário para os indígenas existentes. (Visconde de Sergimirim, 1874; Visconde de Sergimirim, 1875). Sergimirim não propunha nada de novo. O problema não eram as propostas, mas a incapacidade da administração pública em promover este âmbito do serviço público.

Em dezembro de 1874, Sergimirim propôs ao Governo Provincial a extinção dos aldeamentos de Pombal, Saco dos Tapuias, Nossa Senhora da Saúde, Bom Jesus da Glória, Nossa Senhora do Sahy, São Fidelis, Santo Antônio, Bom Jesus em Nazaré, Pedra Branca e 
Jeremoabo. (Visconde de Sergimirim, 1874a, 1875; Ministério da Agricultura, 1874). Em novembro de 1878, o Ministério da Agricultura autorizou ao Governo Provincial a declarar extintos os aldeamentos que de fato já estavam. Foram, portanto, extintos os de Pombal, Nossa Senhora da Saúde, Bom Jesus da Glória, São Fidelis e Jeremoabo e foi nomeada uma Comissão pelo Governo Imperial para medir as terras desses aldeamentos. O trabalho de medição foi iniciado, mas por falta de verbas a Comissão encarregada se dispersou. (BULCÃO, 1879, p. 63-64; Visconde de Sergimirim, 1873e, 1879; ALVES, 1878a;1878b).

Em 1881, Barão do Rio Real, Diretor Geral dos Índios, propôs ao Presidente da província a nomeação dos diretores para Pombal e Soure. Haviam sido extintos ou não estes aldeamentos? Para a Assembleia Legislativa, apesar de não ter encontrado os Atos de extinção, era correto considerar extintos os aldeamentos de Pombal, Saúde e Jeremoabo e justificou a nomeação dos diretores alegando que os trabalhos de medição das terras não haviam sido concluídos. Eram, por isso, necessários os diretores para administrar as terras, enquanto o Governo Imperial não decidisse a respeito. (Barão do Rio Real, 1881). Esse episódio demonstra a ineficiência dos trabalhos de demarcação das terras dos aldeamentos e do abandono do serviço de catequese e civilização dos índios. Em 1887, o Presidente da província da Bahia assim retratava a situação dos aldeamentos:

\footnotetext{
Pequeno é o número de aldeamentos de índios ainda existentes nesta Província. Alguns foram extintos oficialmente, muitos desapareceram constituindo-se em povoados e freguesias, com a retirada dos descendentes dos seus primitivos habitantes. Foi isto devido ao quase abandono em que caiu este ramo do serviço público. (MELLO, 1887, 156).
}

\section{Considerações finais}

Na província da Bahia, entre 1836 e 1887, a administração de catequese e civilização dos índios, entendida como um âmbito do serviço público e exercida em vista da assimilação dos povos originários à sociedade, foi orientada e regida pelo Decreto provincial $n^{\circ} 32$ de 5 de março de 1836 e pelo Decreto $n^{\circ} 426$, de 24 de julho de 1845 que aprovou o Regulamento de catequese e civilização dos índios. A administração deste ramo do serviço público na província da Bahia não obteve os resultados esperados. O Decreto provincial de 1836 e o Regulamento de 1845 enfrentaram grandes dificuldades em executar o projeto de catequese e civilização dos índios.

O Decreto provincial de 1836 adotou o velho sistema de aldeamentos como sistema para catequizar e civilizar os povos originários, mas não deu orientações concretas para sua administração. Na verdade, este decreto já nasceu com um grave defeito, isto é, faltava o 
material humano para executá-lo: confiou a tarefa de catequese a missionários e párocos que numericamente eram insuficientes para executar a tarefa de catequese.

A aplicação do Regulamento de 1845 foi dificultada pela própria ineficiência do Governo Provincial, por falta de recursos econômicos e, ao longo dos anos, por descrença neste ramo do serviço público. A carência de missionários também contribuiu para a ineficiência do plano de catequese e civilização dos índios. Além disso, boa parte do Regulamento estava obsoleta para a realidade que os indígenas estavam vivendo, principalmente nos antigos aldeamentos e nas vilas de índios.

A aplicação do Regulamento de 1845 foi obstaculizada também por falta de pessoas idôneas para o cargo de diretor nos aldeamentos. Muitos deles se aproveitaram do cargo para benefício próprio: não arrecadavam bem as rendas das terras, ou se o faziam não aplicavam em benefício dos indígenas e não prestavam conta ao Diretor Geral dos índios. Em vez de tutelar as terras, eles eram os primeiros a usurpá-las em conluio com os arrendatários. Tanto estes como os que desenvolviam bem suas funções se envolveram em um emaranhado de intrigas que resultava ineficiente a diretoria.

$\mathrm{Na}$ medida que os diretores locais foram nomeados para os antigos aldeamentos e as vilas de índios, exasperou o conflito entre diretores, as autoridades locais (as Câmaras Municipais, juízes, delegados), os rendeiros e os indígenas pela posse e administração das terras nestes lugares. Manuela Carneiro da Cunha, falando das características da política indigenista do século XIX, afirma que neste século "pode-se dizer que a questão indígena deixou de ser essencialmente uma questão de mão-de-obra para se tornar uma questão de terra”. (CUNHA, 1992, p. 133). Podemos dizer também que a questão indígena, principalmente a partir da segunda metade do século XIX, deixou de ser uma questão de catequese e civilização para se tornar uma questão de terra.

No contexto das disputas de terra, questionou-se sobre a identidade dos povos originários. Jogou-se sobre a existência ou não de indígenas nas localidades, sobre a sua civilização ou incivilidade e principalmente sobre quem era indígena legítimo/puro ou mameluco/misturado. Dependendo dos interesses particulares em jogo, afirmou-se ou negou a "indianidade" dos nativos. Do ponto de vista do grau de relação social-cultural os indígenas foram classificados como civilizados, domesticados, batizados e misturados. Procurou-se negar a identidade indígena para contestar o direito que eles tinham sobre a propriedade coletiva das terras dos aldeamentos garantidos por lei e ressaltou-se sua civilidade para afirmar que já não precisavam mais de diretoria e de leis especiais. (Câmara municipal de Mirandela, 1833b; Barberino, 1835; Espinola, 1849;; Nunes, 1851; Franco, 1851). 
Os indígenas dos antigos aldeamentos e das vilas de índios foram conscientes do direito à propriedade coletiva das terras doadas aos aldeamentos. Eles ressaltaram o caráter de indigenato ${ }^{9}$, protestaram contra a usurpação das terras e reivindicaram este direito diante das autoridades. Segundo Manuela Carneiro da Cunha, "O título dos índios sobre suas terras é um título originário, que decorre do simples fato de serem índios: esse título do indigenato, o mais fundamental de todos, não exige legitimação. (CUNHA, 1992, p. 141-142).

O Regulamento de 1845, acabou contribuindo para escancarar ainda mais os conflitos em torno das terras dos antigos aldeamentos e vilas de índios e sua progressiva usurpação, processo este ainda em andamento em diversas partes do Brasil.

\section{Fontes manuscritas}

ABAIXO-ASSINADO DOS ÍNDIOS DA ALDEIA DE S. FIDELIS. 04 jul. 1835. APEB, Seção Colonial/Provincial, Maço 1453.

ABAIXO-ASSINADO DOS ÍNDIOS DA VILA DE SANTARÉM. 1846. APEB, Seção Colonial/Provincial, Maço 4613.

ALVES, Paulo Ferreira. [Correspondências]. 05 jul. 1878a; 11 jul. 1878b. APEB, Seção Colonial/Provincial, Maço 4614.

AMARAL, Antônio Joaquim A. do. [Ofício]. Palácio do Governo da Bahia: 20 fev. 1836. APEB, Seção Legislativa, Série Ofícios Recebidos e Expedidos, Maço 1132.

ÁVOLA, Fidelis de. [Relatório]. Rio de Janeiro, 18 dez. 1886. APF, FSCAM, Vol. 15, ff. 169r172 r.

BARÃO DE S. LOURENÇO. [Ato (cópia)]. 03 abr. 1869. APEB, Seção Colonial/Provincial, Maço 4614.

BARÃO DO RIO REAL. [Ofício]. 01 jun. 1881. APEB, Seção Colonial/Provincial, Maço 4614.

BARBERINO, José Quitel. [Ofício]. Jacobina: 25 set. 1835. APEB, Seção Colonial/Provincial, Maço 7143.

CÂMARA DE VILA VERDE. [Ofícios]. Vila Verde: 21 fev. 1848; 30 jan. 1829. APEB, Seção Colonial/Provincial, Maço 1462.

CÂMARA MUNICIPAL DA VILA DE INHAMBUPE. [Ofício]. Vila de Inhambupe: 28 fev. 1826. APEB, Seção Colonial/Provincial, Maço 1319.

CÂMARA MUNICIPAL DA VILA DE TRANCOSO. [Ofícios]. 19 fev. 1849; 03 fev. 1830. APEB, Seção Colonial/Provincial, Março 1448.

CÂMARA MUNICIPAL DE BARCELOS. [Ófício]. 09 mai. 1849b. APEB, Seção Colonial/Provincial, Maço 1253.

CÂMARA MUNICIPAL DE BARCELOS. [Ofícios]. 03 mar. 1849a; 19 set. 1851; 01 set. 1869. APEB, Seção Colonial/Provincial, Maço 1251.

CÂMARA MUNICIPAL DE ILHÉUS. [Ofício]. 12 jul. 1832. APEB, Seção Colonial/Provincial, Maço 1316.

CÂMARA MUNICIPAL DE JACOBINA. [Ofício]. 15 mar. 1851. APEB, Seção Colonial/Provincial, Maço 1328.

\footnotetext{
9 A tese do "indigenato" considera que o direito indígena às terras de ocupação tradicional é um direito "congênito" e "originário", isto é, antecedente ao próprio Direito. (CAVALCANTE, 2016, p. 22).
} 
CÂMARA MUNICIPAL DE MIRANDELA. [Edital]. 04 jun. 1833b. APEB, Seção Colonial/Provincial, Maço 1357.

CÂMARA MUNICIPAL DE MIRANDELA. [Ofício]. 08 jun. 1833a. APEB, Seção Colonial/Provincial, Maço 1357.

CÂMARA MUNICIPAL DE NAZARETH. [Ofício]. 01 de abr. 1869. APEB, Seção Colonial/Provincial, Maço 1368.

CÂMARA MUNICIPAL DE POMBAL. [Ofício]. Pombal: 30 out. 1829. APEB, Seção Colonial/Provincial, Maço 1381.

CÂMARA MUNICIPAL DE PORTO SEGURO. [Ofício]. 18 dez. 1830. APEB, Seção Colonial/Provincial, Maço 1383.

CÂMARA MUNICIPAL DE PRADO. [Ofícios]. 28 dez. 1831; 29 mar. 1832. APEB, Seção Colonial/Provincial, Maço 1385.

CÂMARA MUNICIPAL DE SANTARÉM. [Ofício]. 23 dez. 1846. APEB, Seção Colonial/Provincial, Maço 4613.

CÂMARA MUNICIPAL DE SANTARÉM. [Ofícios]. 10 jun. 1848. APEB, Seção Colonial/Provincial, Maço 1419.

CÂMARA MUNICIPAL DE SOURE. [Ofícios]. Soure: 18 mai. 1828; 14 jun. 1849. APEB, Seção Colonial/Provincial, Maço 1444.

CẨMARA MUNICIPAL DE VALENÇA. [Ofício]. Valença: 23 out. 1829. APEB, Seção Colonial/Provincial, Maço 1452.

COELHO, Francisco Ramiro de Assis [Ofício (cópia)]. Palácio do Rio de Janeiro, 05 fev. 1840. ASV, Arch. Nunz. Brasile, b. 7, fasc. 29, ff. 163r-163v.

CONCEIÇÃO, Dionísio da. [Correspondência]. 27 ago. 1823.

DEIRÓ, Pedro Eunapio da Silva. [Relatório]. 19 out. 1860. APB, Seção Colonial/Provincial, Maço 7030.

DORIA, José Jacome. [Ofícios]. Bahia: out. 1860a; 28 jan. 1860b; 30 nov. 1860c; 16 dez. 1858. APEB, Seção Colonial/Provincial, Maço 4612.

DORIA, José Jacome. [Ofício]. Bahia: 13 jan. 1862. APEB, Seção Colonial/Provincial, Maço 4612.

ESPINOLA, Manoel José. [Ofício]. Valença: 30 abr. 1849. APEB, Seção Colonial/Provincial, Maço 2630.

FALERNA, Francisco Antônio de. [Correspondência]. Rio de Contas: 25 dez. 1855. APEB, Seção Colonial/Provincial, Maço 4611.

FERREIRA, José Antônio. Com cópia do Alvará de 23 de novembro de 1700. Bahia: 12 jul. 1827. APEB, Seção Colonial/Provincial, Maço 4613.

FRANCO, Santos Pereira. Lista dos índios. 10 abr. 1851. APEB, Seção Colonial/Provincial, Maço 1237.

GENOVA, Paolo Maria de. [Correspondência]. 13 mai. 1836. APEB, Seção Colonial/Provincial, Maço 4613.

GUIMARÃES, Antônio Peixoto. [Ofícios]. Canavieiras e Freguesia de São Boaventura do Poxim: 21 ago. 1828a; 12 dez. 1828b. APEB, Seção Colonial/Provincial, Maço 2318.

JOSÉ, Gaspar. [Correspondênci]. 06 mai. 1861. APEB, Seção Colonial/Provincial, Maço 4612.

JUNIOR, Manoel Luiz Gomes. [Ofício]. Mirandela: 21 jun. 1833. APEB, Seção Colonial/Provincial, Maço 2486.

LIMA, Manoel Ignácio de. [Ofício]. Bahia: 24 fev. 1848. APEB, Seção Colonial/Provincial, Maço 4611.

LIMA, Manoel Ignácio de. [Relatório - cópia]. Bahia: 09 jul. 1847. APEB, Seção Colonial/Provincial, Maço 4611. 
LOBÃO, Alexandre Pinto. [Ofício]. Vila de Itapicuru, 16 set. 1860. APEB, Seção Colonial/Provincial, Maço 4612.

MADUREIRA, Casemiro de Sena. [Ofício]. Bahia: 21 mar. 1850. APEB, Seção Colonial/Provincial, Maço 4611.

MADUREIRA, Casemiro de Sena. [Ofícios]. Bahia: 03 out. 1854a; 04 nov. 1854b; 29 nov. 1854c; 15 mai. 1854d; 20 fev. 1855a; 04 mai. 1855b; 31 jan. 1855c. APEB, Seção Colonial/Provincial, Maço 4612.

MADUREIRA, Casemiro de Sena. [Relatório]. Bahia: 03 mai. 1856. APEB, Seção Colonial/Provincial, Maço 4612.

MATTOS, Pasqual Pereira. [Ofício (cópia)]. Bahia. 03 abr. 1869. APEB, Seção Colonial/Provincial, Maço 1368.

MINISTÉRIO DA AGRICULTURA. [Ofício]. Rio de Janeiro: 23 dez. 1874. APEB, Seção Colonial/Provincial, Maço 770.

NUNES, Bernardino Manoel. [Ofício]. 03 abr. 1851. APEB, Seção Colonial/Provincial, Maço 1237.

PADILHA, Antônio do Desterro. [Correspondências]. Rodelas: 08 mar. 1821a, 08 mar. 1821b. APEB, Seção Colonial/Provincial, Maço 4613.

RESPOSTA À REPRESENTAÇÃO DOS ÍNDIOS. 08 jul. 1833. APEB, Seção Colonial/Provincial, Maço 1357.

RIBEIRO, Francisco Antônio. [Correspondência]. 17 nov. 1853. APEB, Seção Colonial/Provincial, Maço 4612.

SANTANA, Pedro José de. [Correspondência]. 1884. APEB, Seção Colonial/Provincial, Maço 4614.

SANTOS, José R. dos. [Correspondência]. Porto Seguro: 11 set. 1825. APEB, Seção Colonial/Provincial, Maço 1462.

SANTOS, José Rozi dos. [Correspondência]. Abrantes: 17 jul. 1850. APEB, Seção Colonial/Provincial, Maço 1237.

SEIXAS, Romualdo Antônio de. [Ofício]. Bahia: 23 out. 1836. APEB, Seção Colonial/Provincial, Maço 5201.

SEIXAS, Romualdo Antônio de. [Ofício]. Bahia: 10 abr. 1839. APEB, Seção Colonial/Provincial, Maço 5202.

SOUSA, Manoel Joaquim Correia e. [Ofícios (cópias)]. Nazareth: 03 abr. 1869a; 13 mai. 1869b. APEB, Seção Colonial/Provincial, Maço 1368.

SOUZA, Manoel Pinto de. [Correspondência]. 04 jun. 1826a. APEB, Seção Colonial/Provincial, Maço 1319.

TINTA, Antônio Francisco. [Ofício]. Nazareth: 03 mai. 1869. APEB, Seção Colonial/Provincial, Maço 1368.

VASCONCELLOS, João Antônio de. [Ofício]. Valença: 24 abr. 1840a. APEB, Seção Legislativa, Maço 1136.

VASCONCELLOS, Joaquim José Pinheiro de. [Ofício-cópia]. Bahia: 26 ago. 1848b. APEB, Seção Colonial/Provincial, Maço 4611.

VIANA, José Antônio Rocha. Lista de nomes dos Índios da Comarca de Itapicuru. Itapicuru: 16 ago. 1869. APEB, Seção Colonial/Provincial, Maço 2425.

VISCONDE DE SERGIMIRIM. [Ofícios]. Bahia: 23 jun. 1873a; 21 fev. 1873b; 17 mar. 1873c; 01 abr. 1873d. APEB, Seção Colonial/Provincial, Maço 4614.

VISCONDE DE SERGIMIRIM. [Ofícios]. Bahia: 15 out. 1870; 05 nov. 1873e; 22 mar. 1879. APEB, Seção Colonial/Provincial, Maço 4614.

VISCONDE DE SERGIMIRIM. [Relatórios]. Bahia: 09 fev. 1874; 07 fev. 1875. APEB, Seção Colonial/Provincial, Maço 4614. 
Fontes publicadas

ALBURQUERQUE, Diego Velho Cavalcanti de. Relatorio apresetado pelo Ministro da Agricultura á Assembléia Geral Legislativa de 1869. Rio de Janeiro: Typographia Universal de E \& H. Laemmert, 1870.

ARAÚJO, José Thomas Nabuco de. Relatório apresentado pelo Ministro dos Negócios da Justiça à Assembleia Geral Legislativa de 1853. Rio de Janeiro: Empresa Typ. De Paula Brito, 1854.

ATAS DAS SESSÕES. Livro 199, 23 mai. 1830. APEB, Seção Legislativa.

ATAS DAS SESSÕES. Livro 206, 23 mar. 1835. APEB, Seção Legislativa.

ATAS DAS SESSÕES. Livro 208, 11 fev. 1836a; 12 fev. 1836b; 23 fev. 1836c. APEB, Seção Legislativa.

AZEVEDO, Antônio Ignacio de. Falla que recitou o Presidente da província da Bahia na abertura da Assembleia Legislativa em 2 de fevereiro de 1847. Bahia: Typ. do Guaycurú de D. Guedes Cabral, Bahia, 1847.

BARÃO DE SÃO LOURENÇO. Relatório que apresentou à Assembleia Legislativa da Bahia em 11 de abril de 1869. Bahia: Typ. de J. G. Tourinho, 1869.

BARRETO, Francisco Xavier Paes. Falla que recitou o Presidente da província da Bahia na abertura da Assembleia Legislativa em 14 de março de 1859. Bahia: Typografia de Antônio Olavo da Franca Gueral, 1859.

BULCÃO, Antônio de Araújo de Aragão. Falla que recitou o Presidente da província da Bahia na abertura da Assembleia Legislativa em $1^{\circ}$ de maio de 1879. Bahia: Typographia do Diário da Bahia, 1879.

CAMARA, Euzebio de Queiroz Coitinho Mattoso. Relatório apresentado pelo Ministro da Justiça à Assembleia Legislativa Geral de 1850. Rio de Janeiro: Typographia Nacional, 1851, p. 29.

COLEÇÃO DE LEIS E RESOLUÇÕES DA ASSEMBLÉIA LEGISLATIVA DA BAHIA. 1835-1838. Volume I. Bahia: Tipografia de Antonio Olavo França Guerra, 1862.

COLLECÇÃO DAS LEIS DO IMPÉRIO DO BRASIL DE 1828. Parte Primeira. Rio de Janeiro: Typographia Nacional, 1878.

COLLECÇÃO DAS LEIS DO IMPERIO DO BRASIL DE 1843. Tomo V, Parte I. Rio de Janeiro: Typographia Nacional, 1843.

COLLECÇÃO DAS LEIS DO IMPERIO DO BRASIL DE 1845. Tomo VIII, Parte II. Rio de Janeiro: Na Typographia Nacional, 1845.

COLLECÇÃO DAS LEIS DO IMPÉRIO DO BRASIL DE 1850. Tomo XI Parte I. Rio de Janeiro: Typographia Nacional, 1850.

COLLECÇÃO DAS LEIS DO IMPÉRIO DO BRASIL DE 1854. Tomo XVII. Parte II. Rio de Janeiro: Typographia Nacional, 1854.

GALVÃO, Manoel Antônio. Relatorio apresetado pelo Ministro dos Negócios da Justiça á Assembléia Geral Legislativa em 1845. Rio de Janeiro: Typ. Imp. e Const. De J. Villeneuve e C.a, 1845.

HENRIQUES, João Antônio de Araújo Freitas. Falla que recitou o Presidente da província da Bahia na abertura da Assembleia Legislativa em $1^{\circ}$ de março de 1872. Bahia: Typ. do Correio da Bahia, 1872.

LEIS E RESOLUÇÕES DA ASSEMBLÉIA LEGISLATIVA DA PROVÍNCIA DA BAHIA. Bahia: 1836. APEB, Seção Legislativa, Série Registros de Leis, Livro 1.

MADUREIRA, Casemiro de Sena. Relatório sobre o Estado das Aldeias dos Indígenas da Província da Bahia, sua população e civilização. In: MARTINS, Francisco Gonçalves. Falla 
que recitou o presidente da província da Bahia na abertura da Assemblea Provincial em $\mathbf{1}^{\circ}$ de março de 1851. Bahia: Typographia Constitucional de Vicente Ribeiro 1851.

MAGALHÃES, João José de Moura. Falla que recitou o presidente da província da Bahia na abertura da Assembleia Legislativa em 25 de março de 1848. Bahia: Typ. de João Alves Portella, 1848.

MALHEIRO, Agostinho Marques Perdigão. A escravidão no Brasil. Ensaio HistóricoJuridico-Social. Rio de Janeiro: Typographia Nacional, 1866.

MELLO, João Capistrano Bandeira de. Falla que recitou o Presidente da província da Bahia na abertura da Assemblea Legislativa em 4 de outubro de 1887. Bahia: Typ. da Gazeta da Bahia, 1887.

PENNA, Herculano Ferreira. Falla que recitou o Presidente da província da Bahia na abertura da Assembléia Legislativa em 10 de abril de 1860. Bahia: Pypografia de Antônio Olavo da Franca Gueral, 1860.

WANDERLEY, João Mauricio. Falla que recitou o Presidente da província da Bahia na abertura da Assembleia Legislativa em $1^{\circ}$ de março de 1855. Bahia: Typ. de A. Olavo da França Guerra e Comp., 1855. Anexo Quadro ${ }^{\circ} 7$ das aldeias da província da Bahia.

WANDERLEY, João Mauricio. Falla que recitou o Presidente da província da Bahia na abertura da Assembleia Legislativa em 10 de março de 1853. Bahia: Typ. Const. de Vicente Ribeiro Moreira, 1853.

\section{Referências bibliográficas}

BRASILEIRO, Sheila. Povo indígena Kiriri: emergência étnica, conquista territorial e faccionalismo. In OLIVEIRA, João Pacheco de (org). A viagem de volta: etnicidade, política e reelaboração cultural no Nordeste indígena. Rio de Janeiro: Contra Capa, 1999, p. 73-74. CAVALCANTE, Thiago Leandro Vieira. (2016), “Terra indígena: aspectos históricos da construção e aplicação de um conceito jurídico". História, 36 (75): 1-22. Disponível em http://www.scielo.br/scielo.php?script=sci_arttext\&pid=S0101-

90742016000100501\&lng=pt\&tlng=pt, consultado em 16/03/2021.

CUNHA, Manuela Carneiro da (Org.). Legislação Indigenista do século XIX: uma compilação: 1808-1889. São Paulo: EDUSP Comissão Pró Índio de São Paulo, 1992.

CUNHA, Manuela Carneiro da. Política indigenista no século XIX. In CUNHA, Manuela Carneiro da (Org.). História dos índios no Brasil. São Paulo: Companhia das Letas, 1992.

MARCIS, Teresinha. A integração dos Índios como súditos do Rei de Portugal: Uma análise do projeto, dos autores e da implementação na capitania de Ilhéus (1758-1822). 2013. Tese (Doutorado em História Social) - Programa de Pós-Graduação em História Social, Universidade Federal da Bahia, Salvador, 2013. Disponível em: https://repositorio.ufba.br/ri/bitstream/ri/13309/1/Tese\%20Teresinha\%20Marcis.pdf. Acesso em: 02 fev. 2021.

PARAÍSO, Maria Hilda Baqueiro. A guerra do Mucuri: conquista e dominação dos povos indígenas em nome do progresso e da civilização. In ALMEIDA, Luiz Sávio de. Índios no Nordeste: temas e problemas 2. Maceió: EDUFAL, 2000.

REGNI, Pietro Vittorino. Os capuchinhos na Bahia. Vol. 2. Salvador: Gráfica Editora Pallotti, 1988. 
RIBEIRO, Edilmar Cardoso. Os índios de Pedra Branca-Bahia (1825-1889): uma história de conflitos e resistência em defesa da terra indígena. Cadernos de História, v.21, n. 35, p. 136171 2020.

Disponível

em:

http://periodicos.pucminas.br/index.php/cadernoshistoria/article/view/23383/17528. Acesso em: 05 fev. 2021.

SOUZA, Bernardo José de. Dicionário da Terra e da Gente do Brasil. $4^{\text {a }}$ edição. São Paulo: Companhia Editora Nacional, 1939b.

VIEIRA, Dilermando Ramos. História do catolicismo no Brasil (1500-1889). Volume 1. Aparecida-SP: Santuário, 2016. 